\title{
Vitamin D and inflammation
}

\author{
John J Cannell ${ }^{1}$, William B Grant ${ }^{2, *}$, and Michael F Holick ${ }^{3}$ \\ ${ }^{1}$ Vitamin D Council; San Luis Obispo, CA USA; ${ }^{2}$ Sunlight, Nutrition, and Health Research Center; San Francisco, CA USA; ${ }^{3}$ Department of Medicine; Section on Endocrinology, \\ Nutrition and Diabetes, Vitamin D, Skin and Bone Research Laboratory; Boston University Medical Center; Boston, MA USA
}

Keywords: cardiovascular disease, C-reactive protein, cytokines, inflammation, randomized controlled trials, tumor necrosis factoralpha, vitamin D

Abbreviations: CRP, C-reactive protein; CXCL9, CXC chemokine ligand 9; E-selectin, ESR, erythrocyte sedimentation rate, F1+2, prothrombin fragment 1+2; IFG, impaired fasting glucose; IL, interleukin; MCP-1, monocyte chemoattractant protein-1; NGAL, neutrophil gelatinase-associated lipocalin; NGT, normal glucose tolerance; ns, not stated; PAI-1, plasminogen activator inhibitor-1; sICAM-1, soluble intracellular adhesion molecule-1; sTNF-R2, soluble tumor necrosis factor $\alpha$ receptor type 2; TAT, thrombin antithrombin complex; TGF- $\beta$, transforming growth factor- $\beta$; TNF- $\alpha$, tumor necrosis factor- $\alpha$

Several studies found an inverse relationship between 25hydroxyvitamin D [25(OH)D] and markers of inflammation. A controversy exists as to whether vitamin D lowers inflammation or whether inflammation lowers $25(\mathrm{OH}) \mathrm{D}$ concentrations. Certainly $25(\mathrm{OH}) \mathrm{D}$ concentrations fall after major surgery. However, is this due to inflammation lowering $25(\mathrm{OH}) \mathrm{D}$ or is $25(\mathrm{OH}) \mathrm{D}$ being metabolically cleared by the body to quell inflammation. We searched the literature and found 39 randomized controlled trials (RCT) of vitamin D and markers of inflammation. Seventeen found significantly reduced inflammatory markers, 19 did not, one was mixed and one showed adverse results. With few exceptions, studies in normal subjects, obesity, type 2 diabetics, and stable cardiovascular disease did not find significant beneficial effects. However, we found that 6 out of 7 RCTS of vitamin $D_{3}$ in highly inflammatory conditions (acute infantile congestive heart failure, multiple sclerosis, inflammatory bowel disease, cystic fibrosis, SLE, active TB and evolving myocardial infarction) found significant reductions. We found baseline and final $25(\mathrm{OH}) \mathrm{D}$ predicted RCTs with significant reduction in inflammatory markers. Vitamin D tends to modestly lower markers of inflammation in highly inflammatory conditions, when baseline $25(\mathrm{OH}) \mathrm{D}$ levels were low and when achieved 25(OH)D levels were higher. Future inquiries should: recruit subjects with low baseline 25(OH)D levels, subjects with elevated markers of inflammation, subjects with inflammatory conditions, achieve adequate final $25(\mathrm{OH}) \mathrm{D}$ levels, and use physiological doses of vitamin D. We attempted to identify all extant randomized controlled trials (RCTs) of vitamin D that used inflammatory markers as primary or secondary endpoints. (c) John J Cannell, William B Grant, and Michael F Holick

*Correspondence to: William B Grant; Email: wbgrant@infionline.net Submitted: 09/17/2014; Revised: 10/21/2014; Accepted: 10/24/2014 http://dx.doi.org/10.4161/19381980.2014.983401

This is an Open Access article distributed under the terms of the Creative Commons Attribution License (http://creativecommons.org/licenses/by/4.0/), which permits unrestricted use, distribution, and reproduction in any medium, provided the original work is properly cited.

\section{Introduction}

Everything from depression ${ }^{1}$ to cardiovascular disease ${ }^{2}$ to cancer $^{3}$ and autoimmune disorders ${ }^{4}$ is theorized as having inflammation as a core etiological factor. In measuring that inflammation, there are general markers of inflammation, such as C-reactive protein (CRP) and erythrocyte sedimentation rate (ESR), but most research on inflammatory markers are focused on the cytokines. ${ }^{5}$ In fact, modulating inflammatory cytokines is now a mainstay of treatment in a number of diseases. ${ }^{6}$

The relationship between vitamin $\mathrm{D}$ and inflammation has been controversial. Some hypothesize that inflammation reduces $25(\mathrm{OH}) \mathrm{D}$ concentration, ${ }^{7-9}$ while others hypothesize increasing vitamin D status reduces inflammation. ${ }^{10-12}$ Those who hypothesize the first explanation, that inflammation lowers $25(\mathrm{OH}) \mathrm{D}$ concentration, theorize that inflammation lowers serum $25(\mathrm{OH})$ $\mathrm{D}$ via oxidative stress resulting in the oxidative catabolism of 25 $(\mathrm{OH}) \mathrm{D}$. They hypothesize that an oxidative environment reduces $25(\mathrm{OH}) \mathrm{D}$ by interfering with key vitamin $\mathrm{D}$ metabolizing enzymes, disturbing the liver's biosynthesis of $25(\mathrm{OH}) \mathrm{D}$, thus lowering $25(\mathrm{OH}) \mathrm{D}$ concentration. However, this is a difficult theory to disprove.

While it has been shown that $25(\mathrm{OH}) \mathrm{D}$ concentrations decline after major surgery, a fact used to support that inflammation lowers $25(\mathrm{OH}) \mathrm{D}$ concentration hypothesis, to our knowledge, the question of metabolic clearance has not been discussed. However, it is clear that $25(\mathrm{OH}) \mathrm{D}$ concentration decline after major surgery. ${ }^{13-15}$ Is that because inflammation lowers $25(\mathrm{OH})$ $\mathrm{D}$ concentration or because $25(\mathrm{OH}) \mathrm{D}$ is metabolically cleared by the body as it utilizes $25(\mathrm{OH}) \mathrm{D}$ by converting it to 1,25 $(\mathrm{OH})_{2} \mathrm{D}_{3}$ to modulate inflammation? That is, perhaps the body uses $25(\mathrm{OH}) \mathrm{D}$ in an effort to heal itself, thus lowering $25(\mathrm{OH})$ D concentration.

As far as the second contention, that vitamin $\mathrm{D}$ decreases inflammation, certainly in vitro studies indicate $1,25(\mathrm{OH})_{2} \mathrm{D}_{3}$ has potent anti-inflammatory properties. ${ }^{16-18}$ Animal studies also indicate $1,25(\mathrm{OH})_{2} \mathrm{D}_{3}$ and its analogs are effective antiinflammatories. ${ }^{19-21}$ The mechanisms by which $1,25(\mathrm{OH})_{2} \mathrm{D}_{3}$ reduces inflammation are multiple. $1,25(\mathrm{OH})_{2} \mathrm{D}_{3}$ affects both 
the innate and adaptive immune systems; the overall effect is a switch from the more inflammatory T-helper 1 (Th1)/Th17 response to the less inflammatory Th2/Treg profile. ${ }^{22}$ In vitro, these effects result in decreased production of pro-inflammatory markers such as: tumor necrosis factor $\alpha$ (TNF-a), interferongamma (IFN-g), interleukin (IL)-2, IL-12, IL-17 and IL-21 but with increased production of anti-inflammatory cytokines such as IL-10. ${ }^{23}$

Some cross-sectional studies have shown a relationship between 25(OH)D and markers of inflammation. In the largest report, Amer and Qayyam studied more than 15,000 subjects from the National Health and Nutrition Examination Survey (NHANES) 2001-2006. ${ }^{24}$ The subjects were divided into low and high $25(\mathrm{OH}) \mathrm{D}$ concentration with a cutoff of $53 \mathrm{nmol} / \mathrm{L}$. In subjects with a $25(\mathrm{OH}) \mathrm{D}<53 \mathrm{nmol} / \mathrm{L}$, serum $25(\mathrm{OH}) \mathrm{D}$ was inversely associated with CRP $(\beta=-0.34 ; P<0.001)$ but there was no significant association between serum $25(\mathrm{OH}) \mathrm{D}$ and CRP in those with serum $25(\mathrm{OH}) \mathrm{D}$ greater than $53 \mathrm{nmol} / \mathrm{L}$ $(\beta=-0.05 ; P=0.07)$.

CRP is not the only inflammatory marker that has been identified as having cross sectional relationships to circulating 25 $(\mathrm{OH}) \mathrm{D}$. Bellia et al. studied the relationship between serum 25 $(\mathrm{OH}) \mathrm{D}$ and several markers of inflammation in 147 morbidly obese subjects. ${ }^{25}$ Mean $25 \mathrm{OHD}$ was $65 \mathrm{nmol} / \mathrm{L}$. In this group, serum $25(\mathrm{OH}) \mathrm{D}$ was significantly inversely correlated not only with CRP $(r=-0.31 ; P=0.043)$, but also with IL-6 $(r=-$ $0.50 ; \mathrm{P}=0.003)$, and TNF- $\alpha(\mathrm{r}=-0.61 ; P=0.001)$.

It's important to note that $25(\mathrm{OH}) \mathrm{D}$ is a marker for sunlight exposure. Also, ultraviolet radiation has effects on the immune system that are independent of vitamin D. ${ }^{26,27}$ If sunlight, in a path or pathways entirely independent of vitamin $\mathrm{D}$, explains the associations of inflammatory markers and $25(\mathrm{OH}) \mathrm{D}$ concentration, then RCTs of vitamin D in markers of inflammation will not find beneficial effects. It is also possible that sunlight and vitamin $\mathrm{D}$ may have complimentary effects on inflammation.

The observation that higher $25(\mathrm{OH}) \mathrm{D}$ is associated with decreased concentration of inflammatory markers suggests that local autocrine production of $1,25(\mathrm{OH})_{2} \mathrm{D}_{3}$ is binding to genes down-regulating pro-inflammatory cytokines and up-regulating anti-inflammatory ones.

If inflammatory conditions decrease $25(\mathrm{OH}) \mathrm{D}$ concentration through metabolic clearance, and the body utilizes vitamin $\mathrm{D}$ to help heal and modulate inflammation, it may mean that higher $25(\mathrm{OH}) \mathrm{D}$ concentration may be beneficial in inflammatory conditions and thus in treating some inflammatory diseases. In support of such a contention, is the finding that higher $25(\mathrm{OH}) \mathrm{D}$ concentration are associated with faster recovery from induced muscle injury. ${ }^{28}$ Furthermore, a RCT of 28 healthy adults found $100 \mu$ day of vitamin $\mathrm{D}_{3}$ enhanced the recovery in peak isometric force after a muscle-damaging event $(P<0.05) .{ }^{29}$ In that study, supplemental vitamin $\mathrm{D}_{3}$ attenuated $(P<0.05)$ the immediate and delayed ( 2 day, 3 day and 7 day) increase in circulating biomarkers of muscle damage.

In its endocrine role $1,25(\mathrm{OH})_{2} \mathrm{D}_{3}$ helps maintain the calcium economy. $1,25(\mathrm{OH})_{2} \mathrm{D}_{3}$ is derived from a cholesterol precursor metabolite to $1,25(\mathrm{OH})_{2} \mathrm{D}_{3}$ (7-dehydrocholesterol), which, when exposed to sunlight, is converted to vitamin $\mathrm{D}_{3}$. Once formed, vitamin $\mathrm{D}_{3}$ enters the circulation and is sequentially hydroxylated first in the liver to $25(\mathrm{OH}) \mathrm{D}$ and then in the kidney and various tissues to $1,25(\mathrm{OH})_{2} \mathrm{D}_{3}$. In its endocrine role, the seco-steroid $1,25(\mathrm{OH})_{2} \mathrm{D}_{3}$ is secreted into the blood by the kidneys and affects downstream target tissues by interacting with the nuclear vitamin D receptors (VDR) to help maintain the calcium economy. Unlike other anti-inflammatories, e.g. corticosteroids, exogenous $1,25(\mathrm{OH})_{2} \mathrm{D}_{3}$ cannot be used as an anti-inflammatory in pharmacological doses because of dose dependent hypercalcemia. ${ }^{30}$

However, a growing literature suggests $1,25(\mathrm{OH})_{2} \mathrm{D}_{3}$ also has autocrine (inside the cell) steroid actions. ${ }^{31,32}$ What is theorized for $1,25(\mathrm{OH})_{2} \mathrm{D}_{3}$ s autocrine actions is that $25(\mathrm{OH}) \mathrm{D}$ is delivered to cells via the blood, transported across the cell membrane by both passive and active transport, ${ }^{33}$ and metabolized into 1,25 $(\mathrm{OH})_{2} \mathrm{D}_{3}$ by intracellular mitochondrial $25(\mathrm{OH}) \mathrm{D}$ 1-hydroxylase (CYP27B1). Under physiological conditions, serum 25(OH) $\mathrm{D}$ concentrations are a thousand fold higher than serum 1,25 $(\mathrm{OH})_{2} \mathrm{D}_{3}$ concentrations. What is not known is the relative membrane transportation rate, both via active and passive mechanisms, of $25(\mathrm{OH}) \mathrm{D}$ and $1,25(\mathrm{OH})_{2} \mathrm{D}_{3}$. If their membrane transportation rates are the same, this may mean that intracellular 25 $(\mathrm{OH}) \mathrm{D}$ concentration are much higher than intracellular 1,25 $(\mathrm{OH})_{2} \mathrm{D}_{3}$ concentrations.

Because the renal production of $1,25(\mathrm{OH})_{2} \mathrm{D}_{3}$ is tightly regulated, increasing vitamin $\mathrm{D}_{3}$ intake does not result in an increase in serum $1,25(\mathrm{OH})_{2} \mathrm{D}_{3}$ concentration. ${ }^{34}$ However, the administration of increasing doses of vitamin $\mathrm{D}_{3}$ will increase the amount of serum 25(OH)D available for trans-membrane transport without changing the amount of serum $1,25(\mathrm{OH})_{2} \mathrm{D}_{3}$ available for trans-membrane transport.

Thus it is theorized, but not currently discoverable for technical reasons, that the intracellular concentration of autocrine-produced $1,25(\mathrm{OH})_{2} \mathrm{D}_{3}$ may greatly exceed the intracellular concentration that can be reached by administering exogenous $1,25(\mathrm{OH})_{2} \mathrm{D}_{3}$ as a pharmaceutical. That is, physiological doses of vitamin $\mathrm{D}_{3}$, i.e., less than $10,000 \mathrm{IU} / \mathrm{d}$, and the resultant increased serum concentration of $25(\mathrm{OH}) \mathrm{D}$, may result in increased intracellular concentration of $1,25(\mathrm{OH})_{2} \mathrm{D}_{3}$, concentration not achievable either from the controlled renal production of $1,25(\mathrm{OH})_{2} \mathrm{D}_{3}$ or the exogenous administration of 1,25 $(\mathrm{OH})_{2} \mathrm{D}$.

There are unresolved technical problems with attempting to prove this theory, as one cannot yet accurately measure intracellular concentration of $1,25(\mathrm{OH})_{2} \mathrm{D}_{3}$ achieved in an autocrine manner compared with the intracellular concentration achieved when $1,25(\mathrm{OH})_{2} \mathrm{D}_{3}$ is delivered in an endocrine manner. However, when vitamin $\mathrm{D}_{3}$ is given, the resultant autocrine intracellular $1,25(\mathrm{OH})_{2} \mathrm{D}_{3}$ concentration may be much higher than that achieved by directly administering exogenous $1,25(\mathrm{OH})_{2} \mathrm{D}_{3}$.

Therefore, the possibility exists that physiological doses of vitamin $\mathrm{D}$ and the resultant higher serum $25(\mathrm{OH}) \mathrm{D}$ concentration may ultimately achieve a high intracellular $1,25(\mathrm{OH})_{2} \mathrm{D}_{3}$ level. If so, vitamin $\mathrm{D}$, like the glucocorticoids, may be clinically useful when used in physiological or perhaps pharmaceutical 
doses as there are between 1,000 and 13,000 VDR-specific genomic binding sites, some of them linked to inflammation. ${ }^{35}$ When healthy adults received $2000 \mathrm{IU}$ vitamin $\mathrm{D}_{3}$ daily for 3 months 291 genes in their immune white blood cells were substantially influenced. These genes were related to as many as 80 metabolic processes including inflammatory pathways. ${ }^{36}$

Any review of the RCT of vitamin D and markers of inflammation is complicated because the studies are so heterogeneous. First, there are studies of various disease states, some much more inflammatory than others. For example, active TB or active lupus is surely more inflammatory than is, for example, obesity or type2 diabetes. Likewise, subjects suffering an acute myocardial infarction are certainly undergoing a much more inflammatory process than are those who have stable cardiovascular disease. If vitamin $\mathrm{D}$ is anti-inflammatory, we assume it will be more likely to show an effect in highly inflammatory diseases.

Also, there are multiple markers of inflammation; it is unlikely that - if vitamin D affects these markers - it would do so to the same degree with each marker. That is, if vitamin D modulates inflammation, it seems likely that some inflammatory markers would be more responsive to vitamin $\mathrm{D}$ than others.

Other factors causing heterogeneity include baseline $25(\mathrm{OH})$ $\mathrm{D}$, final $25(\mathrm{OH}) \mathrm{D}$, baseline markers of inflammation, dose of vitamin $\mathrm{D}$ used, type of vitamin $\mathrm{D}$ used $\left(\mathrm{D}_{2}\right.$ or $\left.\mathrm{D}_{3}\right)$ and duration of treatment.

In any definitive RCT of vitamin D used as a drug to modulate inflammation, final achieved $25(\mathrm{OH}) \mathrm{D}$ concentration must be adequate not to miss a treatment effect although no one knows what adequate is. Certainly, as we will see, RCTs of vitamin D and markers of inflammation using physiological doses of vitamin $\mathrm{D}$ are rare.

We somewhat arbitrarily categorized physiological doses of vitamin $\mathrm{D}$ as the doses theorized to optimize all vitamin $\mathrm{D}$ requirements, which are currently under debate. If nature is any guide as to natural $25(\mathrm{OH}) \mathrm{D}$ concentration, $25(\mathrm{OH}) \mathrm{D}$ concentration of lifeguards range from 100 to $200 \mathrm{nmol} / \mathrm{L}$. ${ }^{37}$ Modern day equatorial hunter-gatherers have mean $25(\mathrm{OH}) \mathrm{D}$ concentration of $115 \mathrm{nmol} / \mathrm{L}{ }^{38}$ Such concentrations require total vitamin $\mathrm{D}$ inputs of more than $125 \mu \mathrm{g} /$ day. For example, when administered 25,100 , or $250 \mu \mathrm{g} / \mathrm{day}$ for 20 weeks during the winter, healthy men utilized approximately $125 \mu \mathrm{g}$ of total vitamin D input/day just to maintain baseline concentration of around $75 \mathrm{nmol} / \mathrm{L} .{ }^{39}$ Therefore, one can argue that physiological doses in sun-deprived individuals needed to maintain natural $25(\mathrm{OH})$ $\mathrm{D}$ concentration of $50 \mathrm{nmol} / \mathrm{L}$ are at least $125 \mu \mathrm{g} /$ day.

In order to accurately study the full effect of vitamin $\mathrm{D}$ in inflammation, it is likely that baseline $25(\mathrm{OH}) \mathrm{D}$ concentration must be low to begin with in order to see an effect, at least when using physiological doses of vitamin D. For example, as CRP is only inversely associated with $25(\mathrm{OH}) \mathrm{D}$ when $25(\mathrm{OH}) \mathrm{D}$ concentrations are below $53 \mathrm{nmol} / \mathrm{L}$, it is unlikely that a randomized controlled trial of vitamin D will lower CRP when baseline 25 $(\mathrm{OH}) \mathrm{D}$ concentration are $>53 \mathrm{nmol} / \mathrm{L}$.

Also, it is possible that vitamin $\mathrm{D}_{3}$ and vitamin $\mathrm{D}_{2}$ may have different effects on markers of inflammation. For example, a RCT of vitamin $\mathrm{D}_{2}$ and muscle damage in 28 subjects found vitamin $\mathrm{D}_{2}$ increased, not decreased, biomarkers of muscle injury compared to placebo. ${ }^{40}$

Finally, to show an effect, the markers of inflammation probably need to be elevated at baseline. That is, it is unlikely that vitamin $\mathrm{D}$ will lower markers of inflammation that are relatively low to begin with. ${ }^{41}$

\section{Findings}

Thirty-nine RCTs fit our qualifications. Table 1 lists each of the 39 studies, the population studied, the medical condition studied, age, number of subjects studied, biomarkers of inflammation used, baseline and final $25(\mathrm{OH}) \mathrm{D}$ concentration dose used, duration of treatment and outcome.

The 39 RCT were heterogeneous with respect to inflammatory processes studied, markers of inflammation studied, baseline concentration of markers of inflammation, baseline concentration of $25(\mathrm{OH}) \mathrm{D}$, final concentration of $25(\mathrm{OH}) \mathrm{D}$, and dose, duration and type of vitamin $\mathrm{D}$ used.

Of those 39 RCTs, 19 showed no effect, 19 showed a significant beneficial effect (on at least one marker), one study showed mixed results (IL-6 improved, TNF was unchanged, and CRP worsened), and a RCT in rheumatoid arthritis showed vitamin $\mathrm{D}_{2}$ worsened TNF- $\alpha$. Of the 19 studies without beneficial effects, 18 were in mildly inflammatory conditions. Of the 19 studies with significant beneficial effects, all were either in highly inflammatory conditions, used doses of vitamin $\mathrm{D}>20 \mu \mathrm{g} /$ day and had baseline CRP $>3$.

The results of the trials in Table 1 can be ordered by baseline and achieved $25(\mathrm{OH}) \mathrm{D}$ concentration and the number of significant and insignificant findings tabulated (Table 2). Trials involving vitamin $\mathrm{D}_{2}$ were not included. Given the relatively small number of trials that dealt with inflammation using vitamin $\mathrm{D}_{3}$, 34 , it was deemed appropriate to divide the data into 2 groups for each ranking. Appropriate breaks appeared to be $51.9 \mathrm{nmol} / \mathrm{L}$ for baseline 25(OH)D and $83 \mathrm{nmol} / \mathrm{L}$ for achieved $25(\mathrm{OH}) \mathrm{D}$. The group with the lower $25(\mathrm{OH}) \mathrm{D}$ concentrations was considered the treatment group, while the other group was considered the control group. The findings from each study were apportioned between significant and not significant at the $\mathrm{p}=0.05$ level, then totaled. A calculator for relative risk with $95 \%$ confidence intervals was used. ${ }^{81}$

For this set of vitamin D RCTs related to inflammation biomarkers, the relative risk for a significant outcome based on baseline $25(\mathrm{OH}) \mathrm{D}$ concentrations divided between 46.7 and $49.0 \mathrm{nmol} / \mathrm{L}$ was 1.40 (95\% CI, 0.84-2.34 (see Table 2). The relative risk for a significant outcome based on achieved $25(\mathrm{OH})$ $\mathrm{D}$ concentrations divided at $83 \mathrm{nmol} / \mathrm{L}$ was 1.79 (95\% CI, 0.84-3.79), with lower achieved $25(\mathrm{OH}) \mathrm{D}$ concentrations being more likely to result in a significant outcome. The likely reason that lower rather than higher achieved $25(\mathrm{OH}) \mathrm{D}$ concentrations were more likely to be associated with a significant outcome is that they were more likely to be associated with lower baseline 25 $(\mathrm{OH}) \mathrm{D}$ concentrations. 25(OH)D-health outcome relations 


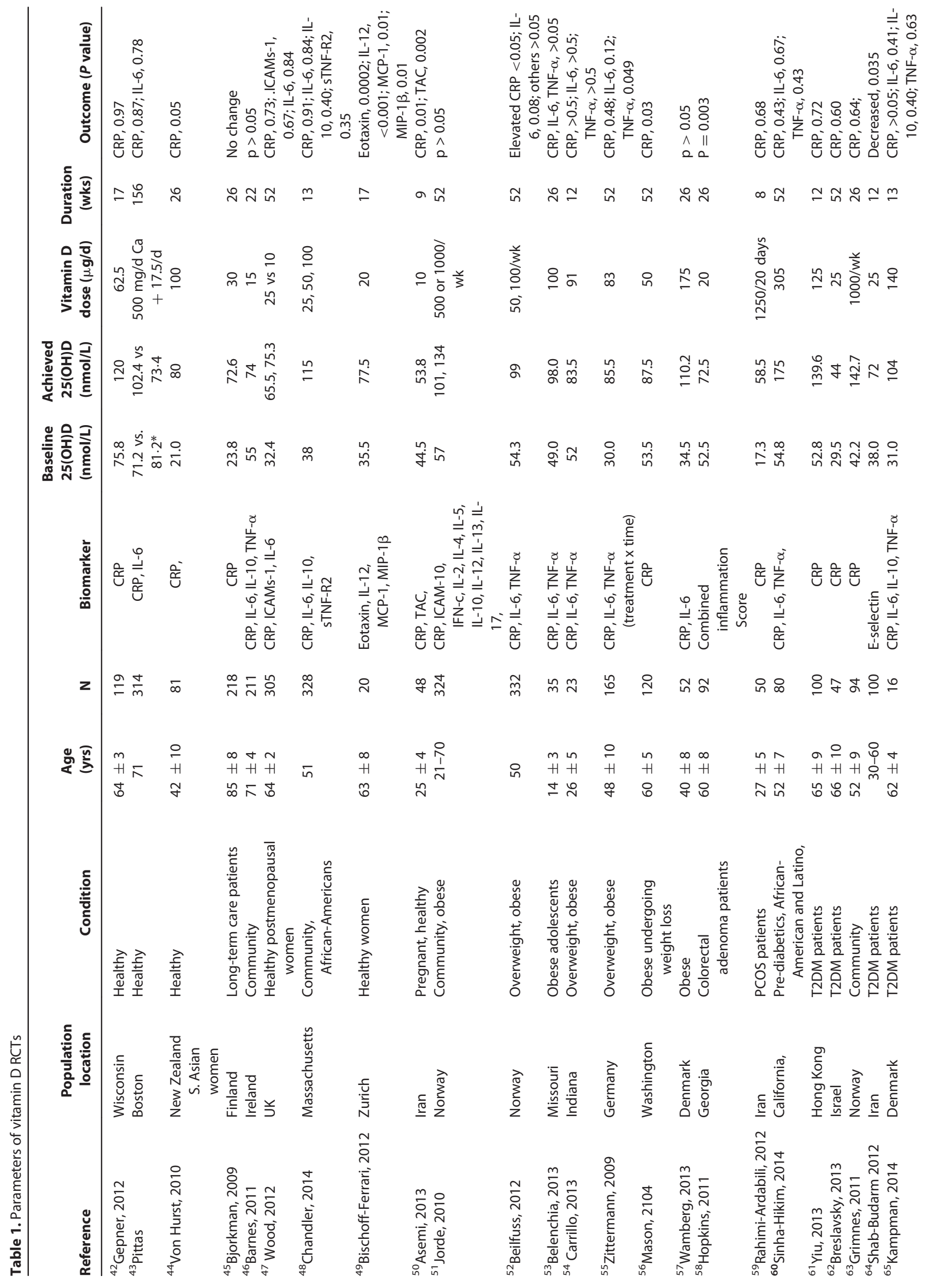




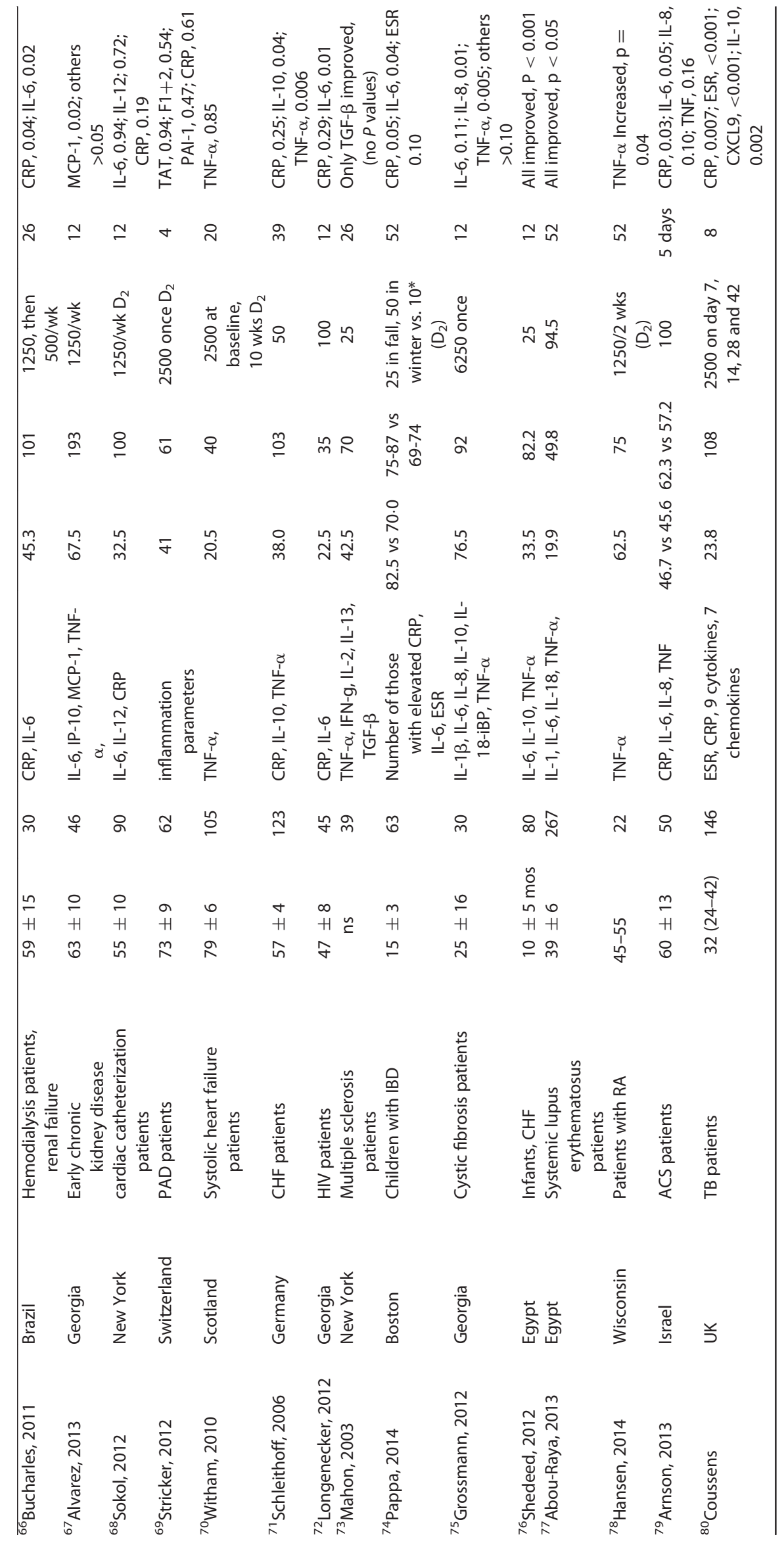


Table 2. Relative risk of a vitamin $D_{3}$ trial finding a significant reduction in inflammation biomarkers based on baseline and achieved $25(\mathrm{OH}) \mathrm{D}$ concentrations

\begin{tabular}{lccccc}
\hline Order & Range (nmol/L) & N & N Successful & N Unsuccessful & Relative Risk of Successful Trial \\
\hline Baseline 25(OH)D concentration & $17.3-46.7$ & 22 & 10.2 & 10.8 & 9.5 \\
Totals & $49.0-76.5$ & 12 & 3.5 & 20.3 & $1.40(95 \% \mathrm{Cl}, 0.84-2 \cdot 34)$ \\
Achieved 25(OH)D concentration & & 34 & 13.7 & & 6.8 \\
Totals & $35-82.2$ & 15 & 8.2 & 13.5 & $1.79(95 \% \mathrm{Cl}, 0.84-3.79)$ \\
\hline
\end{tabular}

$\mathrm{Cl}$, confidence interval; $\mathrm{N}$, number of trials.

change rapidly for $25(\mathrm{OH}) \mathrm{D}$ concentrations below $50 \mathrm{nmol} / \mathrm{L}$, then change slowly for higher values. ${ }^{82,83}$

These results are consistent with the guidelines for clinical trials for nutrient effects proposed by Robert Heaney. ${ }^{84}$ Two important guidelines were that those enrolled in the trials should have values of the nutrient marker of interest at the lower end of the nutrient-health outcome relationship, and then be given in sufficient enough amounts to raise the marker to the upper end of the relationship.

The implication of this finding is that unless those enrolled in vitamin $\mathrm{D}$ trials have low $25(\mathrm{OH}) \mathrm{D}$ concentrations, the trails are unlikely to find significant beneficial effects. This finding helps explain why few vitamin D RCTs have found significant beneficial effects, as noted by Autier ${ }^{7}$ and others. This finding also suggests that the major vitamin D trials underway, such as VITAL, ${ }^{85}$ will be unlikely to find significant beneficial effects except in those participants with low baseline $25(\mathrm{OH}) \mathrm{D}$ concentrations.

\section{Discussion}

As our review suggests, the effectiveness of vitamin $\mathrm{D}$ in lowering markers of inflammation appears to depend mainly on the disease state studied and baseline $25(\mathrm{OH}) \mathrm{D}$ concentrations. Some conditions are more inflammatory than others. For example, active TB or evolving myocardial infarction is surely more inflammatory than is, for example, obesity. Likewise, subjects with SLE are certainly undergoing more inflammation than are subjects with stabletype-2 diabetes.

We found that 7 out of 8 RCTS of vitamin $\mathrm{D}_{3}$ in highly inflammatory conditions (acute infantile congestive heart failure, multiple sclerosis, inflammatory bowel disease, cystic fibrosis, SLE, active TB and evolving myocardial infarction) found significant beneficial effects. One study in rheumatoid arthritis showed an adverse effect but that study used vitamin $1250 \mu \mathrm{g} /(2$ weeks $)$ of $\mathrm{D}_{2}$ not $\mathrm{D}_{3}$.

The most meticulous of the studies in highly inflammatory conditions (active TB), Coussens et al, ${ }^{81}$ started with baseline CRP of $62.5 \mathrm{mg} / \mathrm{L}$ in the treatment group and it fell to $15.5 \mathrm{mg} / \mathrm{L}$ while the initial CRP in the placebo group was $62 \mathrm{mg} / \mathrm{L}$ initially and it fell to $19 \mathrm{mg} / \mathrm{L}$ after 8 weeks of antitubercular treatment $(P \leq 0.0072)$. Although highly significant, the effect on CRP was modest at best.
To put these findings in context, it is useful to compare vitamin D's anti-inflammatory actions to those of a corticosteroid. ${ }^{86}$ When $12.5 \mathrm{mg} /$ day of prednisone/day was used to treat polymyalgia rheumatic, ESR declined from 60 to $20 \mathrm{~mm} /$ hour and CRP declined from 30 to $5 \mathrm{mg} / \mathrm{dl}$ within one week. However, prednisone in such doses is not free from serious side effects while physiological doses of vitamin $\mathrm{D}$ appear to be.

In looking at the conditions studied, in normal subjects, 7 of the 8 studies found no beneficial effects including 2 studies using low physiological doses of vitamin $\mathrm{D}_{3}(63 \mu \mathrm{g} /$ day and $100 \mu \mathrm{g} /$ day). The only RCT with beneficial effects in normal subjects was a small study that used calcidiol $[25(\mathrm{OH}) \mathrm{D}]$ instead of cholecalciferol (vitamin $\mathrm{D}_{3}$ ) as the intervention. The dose of 25 $(\mathrm{OH}) \mathrm{D}$ used were supra-physiological, equivalent of up to $200 \mu \mathrm{g} /$ day of vitamin $\mathrm{D}_{3}{ }^{87}$

Four of the 7 studies in obesity did not find beneficial effects, one was mixed, and the 2 RCTs with beneficial effects were of marginal significance or only significant among high compliers. It does not appear vitamin $\mathrm{D}$ significantly lowers markers of inflammation in obesity.

As we said, such studies are complicated by the wide variation in doses of vitamin D used as well as the method of administration. Six studies used monthly bolus dosing or a greater time interval and 2 of them found significant beneficial effects. As far as dose, some studies attempted to modulate inflammatory markers using doses as low as $200 \mathrm{IU} /$ day of vitamin $\mathrm{D}_{3}$, while others used 15,000 $\mu \mathrm{g}$ every month, and one used $20 \mu \mathrm{g} /$ day of calcidiol, which, as noted above, may be equivalent of $200 \mu \mathrm{g} /$ day of vitamin $\mathrm{D}_{3}$.

In the 6 studies that used vitamin $\mathrm{D}_{2}$ as treatment, 4 of 6 showed no effect, one found a beneficial effect, and one showed a detrimental effect. That is, only one of the 6 studies of vitamin $\mathrm{D}_{2}$ showed a treatment effect while one of the studies without benefits showed adverse effects on markers of inflammation (in rheumatoid arthritis).

Multiple and different markers of inflammation were used in the various studies. CRP was the most commonly used marker; it was used in 26 studies. Vitamin D showed a treatment effect in only 8 of the 26 studies that used CRP, although some of the studies using CRP also used other markers. TNF- $\alpha$ was used as a marker in 16 studies, 4 of which showed a treatment effect. However, studies of highly inflammatory conditions tended to show vitamin $\mathrm{D}$ reduced both markers. The marker that showed the 
most significant decline with vitamin $\mathrm{D}$ treatment compared to placebo was the chemokine CXCL9 $\left(\mathrm{P}=5.92 \times 10^{-12}\right)$ in Coussens et al. ${ }^{81}$

We found 2 remarkably well conducted RCTs without benefits in low inflammatory conditions (old age and obesity) that met most of our proposed criteria (initial $25(\mathrm{OH})$ $\mathrm{D}<50 \mathrm{nmol} / \mathrm{L}$, final $25(\mathrm{OH}) \mathrm{D}>75 \mathrm{nmol} / \mathrm{L}$; baseline CRP elevated, and physiological doses of vitamin $\mathrm{D}_{3}$ used). For example, Bjorkman et al randomized 218 long-term elderly inpatients to receive either placebo or 16,800 IU Q 2 weeks of vitamin $\mathrm{D}_{3}$ for 6 months. ${ }^{46}$ Baseline $25(\mathrm{OH}) \mathrm{D}$ was $23 \mathrm{nmol} / \mathrm{L}$ and final 25 $(\mathrm{OH}) \mathrm{D}$ was $70 \mathrm{nmo} / \mathrm{L}$. Baseline CRP was relatively high at $10.86 \mathrm{mg} / \mathrm{L}$. However, at the end of the trial CRP was not significantly different between groups. Likewise, Warmberget et $\mathrm{al}^{58}$ randomized 52 obese subjects to either 7,000 IU of vitamin $\mathrm{D}_{3} /$ day or placebo. Mean $25(\mathrm{OH}) \mathrm{D}$ went from $33 \mathrm{nmol} / \mathrm{L}$ at baseline to $113 \mathrm{nmol} / \mathrm{L}$ at 26 weeks. Baseline CRP was $7.4 \mathrm{mg} / \mathrm{ml}$. There was no difference between groups at the end of the study.

In the studies we reviewed, vitamin $\mathrm{D}$ was studied in subphysiological and physiological doses. ${ }^{88}$ We could not identify any RCT that used pharmaceutical doses of vitamin D in inflammation although one study used $800 \mathrm{IU} /$ day of calcidol, the equivalent of up to $8,000 \mathrm{IU} /$ day, and showed a treatment effect in rather arcane markers of inflammation in normal subjects.

If vitamin $\mathrm{D}$ was an investigational drug, one of the first things pharmaceutical companies would do are dose ranging studies to find the highest dose of the drug that does not cause significant side effects, that is the pharmacological dose. This is important if vitamin $\mathrm{D}$ is to be used as a drug, lest a treatment effect be missed with too low of a dose. With the exception of one outlier study, in a meticulous review as noted above, Vieth found the equivalent of 50,000 IU/day did not cause hypercalcemia and was apparently free of serious short-term side effects ${ }^{89}$

While pharmaceutical doses of vitamin D are unknown, in our review we found 5 of the 42 studies used the equivalent of more than 5,000 IU/day of vitamin D. None of the final achieved $25(\mathrm{OH}) \mathrm{D}$ concentration exceeded the usual upper limit of normal $25(\mathrm{OH}) \mathrm{D}$ ranges $(250 \mathrm{nmol} / \mathrm{L})$ so it can be argued these were not supra-physiological doses. Three of the 5 studies using such doses found beneficial effects.

\section{Conclusions}

In highly inflammatory conditions, where markers of inflammation are high at baseline, 6 of 8 RCTs show vitamin $\mathrm{D}_{3}$ modestly reduced markers of inflammation with one study of vitamin $\mathrm{D}_{2}$ showed an adverse effect.

As far as the chicken and the egg question of does vitamin D lower inflammation or does inflammation lower vitamin D concentration, we conclude RCTs show that improving vitamin D status modestly lowers most markers of inflammation in highly inflammatory conditions. However, it is possible that both mechanisms are at play. That is, vitamin D may decrease inflammation and oxidative stress from inflammation may interfere with the metabolism of vitamin D and thus lower $25(\mathrm{OH}) \mathrm{D}$. The 2 are not mutually exclusive.

After reviewing the above RCTs, we conclude that future RCTs of vitamin D in inflammation and disease should meet the following criteria:

1. Study markedly inflammatory medical conditions;

2. Have elevated baseline markers of inflammation;

3. Have mean baseline $25(\mathrm{OH}) \mathrm{D}$ concentration $<45 \mathrm{nmol} / \mathrm{L}$;

4. Use doses of vitamin $\mathrm{D}_{3}$ sufficient to raise $25(\mathrm{OH}) \mathrm{D}$ concentration to $>85-100 \mathrm{nmol} / \mathrm{L}$.

Modern studies of the clinical use of physiological doses of vitamin D are relatively rare (around 5,000 IU/day, see above). At least one RCT of physiological doses shows vitamin D may be clinically helpful as add on treatment in multiple sclerosis, ${ }^{89}$ active tuberculosis, ${ }^{90}$ rheumatoid arthritis, ${ }^{91}$ and lupus, ${ }^{92}$ all inflammatory diseases. All clinical treatments decisions are based on a risk/benefit analysis. As the risk of physiological doses of vitamin $\mathrm{D}$ is low, ${ }^{93}$ clinicians should consider using physiological doses of vitamin $\mathrm{D}$ as add on therapy in inflammatory conditions until RCTs of such doses show it to be of no value.

\section{Method}

To try to answer some of these questions, we attempted to review all the RCTs of vitamin D and inflammatory markers published in the English language as of July, 2014. We searched the National Library of Medicine for key words, "vitamin D" and "inflammation," and "controlled trial." We obtained 60 references and then scoured those publications for additional references. For every RCT found, we also searched for similar studies using that Medline search feature. We excluded RCT of $1,25(\mathrm{OH}) \mathrm{D}_{2} \mathrm{D}_{3}$ or its analogs. We then examined these 60 references for outcomes related to inflammation, which reduced the number of studies included to 39 . We then examined whether the inflammation outcomes were significant to the $\mathrm{p}<0.05$ level. In determining the success of the trials in terms of baseline and achieved $25(\mathrm{OH}) \mathrm{D}$ concentration, we used the ratio of significant inflammation to total inflammation outcomes for each study. Since we did not follow the rules for systematic reviews, this review should be considered a narrative review.

\section{Disclosure of Potential Conflicts of Interest}

JJC is director of the Vitamin D Council, earns royalties from Purity Products Inc., and is on the Scientific Advisory Board for OPKO Health Inc.

WBG is the Director of Sunlight, Nutrition and Health Research Center, San Francisco. This organization receives funding from Bio-Tech Pharmacal (Fayetteville, AR) and Medi-Sun Engineering, LLC (Highland Park, IL). 


\section{References}

1. Han QQ, Yu J. Inflammation: a mechanism of depression? Neurosci Bull 2014; 30:515-23; PMID:24838302; http://dx.doi.org/10.1007/s12264-013-1439-3

2. Christodoulidis G, Vittorio TJ, Fudim M, Lerakis S, Kosmas CE. Inflammation in coronary artery disease. Cardiol Rev 2014; 22:279-88; PMID:24441047; http://dx.doi.org/10.1097/CRD.0000000000000006

3. Taniguchi K, Karin M. IL-6 and related cytokines as the critical lynchpins between inflammation and cancer. Semin Immunol 2014; 26:54-74; PMID:24552665; http://dx.doi.org/10.1016/j.smim.2014.01.001

4. Skapenko A, Leipe J, Lipsky PE, Schulze-Koops H. The role of the $\mathrm{T}$ cell in autoimmune inflammation. Arthritis Res Ther 2005; 7Suppl; 2:S4-14; http://dx. doi.org/10.1186/ar1703

5. Commins SP, Borish L, Steinke JW. Immunologic messenger molecules: cytokines, interferons, and chemokines. J Allergy Clinimmunol 2010; 125:S53-72; http://dx.doi.org/10.1016/j.jaci.2009.07.008

6. Tayal V, Kalra BS. Cytokines and anti-cytokines as therapeutics-an update. Eur J Pharmacol 2008; 579:112; PMID:18021769; http://dx.doi.org/10.1016/j. ejphar.2007.10.049

7. Autier P, Boniol M, Pizot C, Mullie P. Vitamin D status and ill health: a systematic review. Lancet Diabetes Endocrinol 2014; 2:76-89; PMID:24622671; http:// dx.doi.org/10.1016/S2213-8587(13)70165-7

8. Henriksen VT, Rogers VE, Rasmussen GL, Trawick RH, Momberger NG, Aguirre D, Barker T. Proinflammatory cytokines mediate the decrease in serum $25(\mathrm{OH}) \mathrm{D}$ concentrations after total knee arthroplasty? Med Hypotheses 2014; 82:134-7; PMID:24332533; http://dx.doi.org/10.1016/j.mehy.2013.11.020

9. Mangge H, Weghuber D, Prassl R, Haara A, Schnedl W, Postolache TT, Fuchs D. The role of vitamin D in atherosclerosis inflammation revisited: more a bystander than a player? Curr Vasc Pharmacol 2013. [Epub ahead of print]; PMID:24329737

10. Guillot X, Semerano L, Saidenberg-Kermanac'h N, Falgarone G, Boissier MC. Vitamin D and inflammation. Joint Bone Spine 2010; 77:552-7; PMID:21067953; http://dx.doi.org/10.1016/j.jbspin. 2010.09.018

11. Adorini L, Penna G. Control of autoimmune diseases by the vitamin D endocrine system. Nat Clin Pract Rheumatol 2008; 4:404-12; PMID:18594491; http:// dx.doi.org/10.1038/ncprheum0855

12. Marcotorchino J, Gouranton E, Romier B, Tourniaire F, Astier J, Malezet C, Amiot MJ, Landrier JF. Vitamin $\mathrm{D}$ reduces the inflammatory response and restores glucose uptake in adipocytes. Mol Nutr Food Res 2012; 56:1771-82; PMID:23065818; http://dx.doi.org/ $10.1002 / \mathrm{mnfr} .201200383$

13. Barker T, Martins TB, Kjeldsberg CR, Trawick RH, Hill HR. Circulating interferon- $\gamma$ correlates with 1,25 $(\mathrm{OH}) \mathrm{D}$ and the $1,25(\mathrm{OH}) \mathrm{D}$-to-25(OH)D ratio. Cytokine 2012; 60:23-6; PMID:22704696; http://dx.doi. org/10.1016/j.cyto.2012.05.015

14. Waldron JL, Ashby HL, Cornes MP, Bechervaise J, Razavi C, Thomas OL, Chugh S, Deshpande S, Ford C, Gama R. Vitamin D: a negative acute phase reactant. J Clin Pathol 2013; 66:620-2; PMID:23454726; http://dx.doi.org/10.1136/jclinpath-2012-201301

15. Reid D, Toole BJ, Knox S, Talwar D, Harten J, O'Reilly DS, Blackwell S, Kinsella J, McMillan DC, Wallace AM. The relation between acute changes in the systemic inflammatory response and plasma 25hydroxyvitamin D concentrations after elective knee arthroplasty. Am J Clin Nutr 2011; 93:1006-11; PMID:21411617; http://dx.doi.org/10.3945/ajcn. 110.008490

16. Guo J, Ma Z, Ma Q, Wu Z, Fan P, Zhou X, Chen L, Zhou S, Goltzman D, Miao D, Wu E. 1, 25(OH $)_{2} \mathrm{D}_{3}$ inhibits hepatocellular carcinoma development through reducing secretion of inflammatory cytokines from immunocytes. Curr Med Chem 2013; 20:4131-41;
PMID:23992309; 09298673113209990248

17. Korf H, Wenes M, Stijlemans B, Takiishi T, Robert $S$, Miani M, Eizirik DL, Gysemans C, Mathieu C. . 1,25Dihydroxyvitamin D3 curtails the inflammatory and T cell stimulatory capacity of macrophages through an IL-10-dependent mechanism. Immunobiology 2012; 217:1292-300; PMID:22944250; http://dx.doi.org/ 10.1016/j.imbio.2012.07.018

18. Feng X, Lv C, Wang F, Gan K, Zhang M, Tan W. Modulatory effect of 1,25-dihydroxyvitamin D 3 on IL1 $\beta$-induced RANKL, OPG, TNF $\alpha$, and IL- 6 expression in human rheumatoid synoviocyte MH7A. Clin Dev Immunol 2013; 2013:160123; PMID:24348674; http://dx.doi.org/10.1155/2013/ 160123

19. Erbaş O, Solmaz V, Aksoy D, Yavaşoğlu A, Sağcan M, Taşkıran D. Cholecalciferol (vitamin D 3) improves cognitive dysfunction and reduces inflammation in a rat fatty liver model of metabolic syndrome. Life Sci 2014; 103:68-72; PMID:24727236; http://dx.doi.org/ $10.1016 /$ j.lfs. 2014.03 .035

20. Adzemovic MZ, Zeitelhofer M, Hochmeister S, Gustafsson SA, Jagodic M. Efficacy of vitamin D in treating multiple sclerosis-like neuroinflammation depends on developmental stage. Exp Neurol 2013; 249:39-48; PMID:23954214; http://dx.doi.org/10.1016/j. expneurol.2013.08.002

21. Yilmaz SS, Hizli D, Yilmaz E, Eryilmaz OG, Hizli F, Haltaş H. Effect of vitamin D on postoperative adhesion formation in a rat uterine horn adhesion model. J Reprod Med 2013; 58:511-6; PMID:24568046

22. Guillot X, Semerano L, Saidenberg-Kermanac'h N, Falgarone G, Boissier MC. Vitamin D and inflammation. Joint Bone Spine 2010; 77:552-7; PMID:21067953; http://dx.doi.org/10.1016/j.jbspin.2010.09.018

23. Aranow C. Vitamin D and the immune system. J Investig Med 2011; 59:881-6; PMID:21527855

24. Amer M, Qayyum R. Relation between serum 25hydroxyvitamin $\mathrm{D}$ and C-reactive protein in asymptomatic adults (from the continuous National Health and Nutrition Examination Survey 2001 to 2006). Am J Cardiol 2012; 109:226-230; PMID:21996139; http://dx.doi.org/10.1016/j.amjcard.2011.08.032

25. Bellia A, Garcovich C, D'Adamo M, Lombardo M, Tesauro M, Donadel G, Gentileschi P, Lauro D, Federici M, Lauro R, et al. Serum 25-hydroxyvitamin D concentration are inversely associated with systemic inflammation in severe obese subjects. Intern Emerg Med 2013; 8:33-40; PMID:21437585; http://dx.doi. org/10.1007/s11739-011-0559-x

26. Hart PH, Gorman S. Exposure to UV wavelengths in sunlight suppresses immunity. To what extent is UVinduced vitamin D3 the mediator responsible? Clin Biochem Rev 2013; 34:3-13; PMID:23592888

27. Wang Y, Marling SJ, McKnight SM, Danielson AL, Severson KS, Deluca HF. Suppression of experimental autoimmune encephalomyelitis by $300-315 \mathrm{~nm}$ ultraviolet light. Arch Biochem Biophys 2013; 536:81-6; PMID:23747577; $\quad$ http://dx.doi.org/10.1016/j. abb.2013.05.010

28. Barker T, Henriksen VT, Martins TB, Hill HR, Kjeldsberg CR, Schneider ED, Dixon BM, Weaver LK. Higher serum 25-hydroxyvitamin D concentrations associate with a faster recovery of skeletal muscle strength after muscular injury. Nutrients 2013; 5:125375; PMID:23595134; http://dx.doi.org/10.3390/ nu5041253

29. Barker T, Schneider ED, Dixon BM, Henriksen VT, Weaver LK. Supplemental vitamin D enhances the recovery in peak isometric force shortly after intense exercise. Nutr Metab (Lond) 2013; 10:69; PMID:24313936; http://dx.doi.org/10.1186/17437075-10-69

30. Holick MF. Vitamin D deficiency. N Engl J Med 2007; 357:266-81; PMID:17634462; http://dx.doi. org/10.1056/NEJMra070553
31. Hewison M. Vitamin D and immune function: autocrine, paracrine or endocrine? Scand J Clin Lab Invest Suppl 2012; 243:92-102; PMID:22536769

32. Holick MF. Vitamin D deficiency. N Engl J Med 2007; 357:266-81; PMID:17634462; http://dx.doi. org/10.1056/NEJMra070553

33. Kaseda R, Hosojima M, Sato H, Saito A. Role of megalin and cubilin in the metabolism of vitamin $\mathrm{D}(3)$ Ther Apher Dial 2011; 15(Suppl 1):147PMID:21595846; http://dx.doi.org/10.1111/j.17449987.2011.00920.x

34. Biancuzzo RM, Clarke N, Reitz RE, Travison TG, Holick MF. Serum concentrations of 1,25-dihydroxyvitamin D2 and 1,25-dihydroxyvitamin D3 in response to vitamin D2 and vitamin D3 supplementation. J Clin Endocrinol Metab 2013; 98:973-9; PMID:23386645; http://dx.doi.org/10.1210/jc.20122114

35. Carlberg C. Genome-wide (over)view on the actions of vitamin D. Front Physiol 2014; 5:167; PMID:24808867

36. Hossein-Nezhad A, Spira A, Holick MF. Influence of vitamin $d$ status and vitamin $\mathrm{D}_{3}$ supplementation on genome wide expression of white blood cells: a randomized double-blind clinical trial. PLoS One 2013; 8: e58725; PMID:23527013; http://dx.doi.org/10.1371/ journal.pone. 0058725

37. Haddad JG, Chyu KJ. Competitive protein-binding radioassay for 25-hydroxycholecalciferol. J Clin Endocrinol Metab 1971; 33:992-5; PMID:4332615; http:// dx.doi.org/10.1210/jcem-33-6-992

38. Luxwolda MF, Kuipers RS, Kema IP, Dijck-Brouwer DA, Muskiet FA. Traditionally living populations in East Africa have a mean serum 25-hydroxyvitamin D concentration of $115 \mathrm{nmol} / \mathrm{l}$. Br J Nutr 2012 108:1557-61; PMID:22264449; http://dx.doi.org/ $10.1017 /$ S0007114511007161

39. Heaney RP, Davies KM, Chen TC, Holick MF, BargerLux MJ. Human serum 25-hydroxycholecalciferol response to extended oral dosing with cholecalciferol. Am J Clin Nutr 2003; 77:204-10; PMID:12499343

40. Nieman DC, Gillitt ND, Shanely RA, Dew D, Meaney MP, Luo B. Vitamin D2 supplementation amplifies eccentric exercise-induced muscle damage in NASCAR pit crew athletes. Nutrients 2013; 6:63-75; PMID:24362707; http://dx.doi.org/10.3390/nu6010063

41. Zanetti M, Harris SS, Dawson-Hughes B. Ability of vitamin $\mathrm{D}$ to reduce inflammation in adults without acute illness. Nutr Rev 2014; 72:95-8; PMID:24330160; http://dx.doi.org/10.1111/nure. 12095

42. Gepner AD, Ramamurthy R, Krueger DC, Korcarz CE, Binkley N, Stein JH. A prospective randomized controlled trial of the effects of vitamin D supplementation on cardiovascular disease risk. PLoS One 2012; 7:e36617; PMID:22586483; http://dx.doi.org/ 10.1371/journal.pone.0036617

43. Pittas AG, Harris SS, Stark PC, Dawson-Hughes B. The effects of calcium and vitamin D supplementation on blood glucose and markers of inflammation in nondiabetic adults. Diabetes Care 2007; 30:980-6; PMID:17277040 http://dx.doi.org/10.2337/dc061994

44. von Hurst PR, Stonehouse W, Coad J. Vitamin D supplementation reduces insulin resistance in South Asian women living in New Zealand who are insulin resistant and vitamin $\mathrm{D}$ deficient - a randomised, placebo-controlled trial. $\mathrm{Br}$ J Nutr 2010; 103:549-55; PMID:19781131; http://dx.doi.org/10.1017/S000711 4509992017

45. Bjorkman MP, Sorva AJ, Tilvis RS.C-reactive protein and fibrinogen of bedridden older patients in a sixmonth vitamin D supplementation trial. J Nutr Health Aging 2009; 13:435-9; PMID:19390750; http://dx. doi.org/10.1007/s12603-009-0080-3

46. Barnes MS, Horigan G, Cashman KD, Hill TR, Forsythe LK, Lucey AJ, McSorley EM, Kiely M, Bonham MP, Magee PJ, et al. Maintenance of wintertime 
vitamin D status with cholecalciferol supplementation is not associated with alterations in serum cytokine concentrations among apparently healthy younger or older adults. J Nutr 2011; 141:476-81; PMID:21270359; http://dx.doi.org/10.3945/jn.110.131516

47. Wood AD, Secombes KR, Thies F, Aucott L, Black AJ, Mavroeidi A, Simpson WG, Fraser WD, Reid DM, Macdonald HM. Vitamin D3 supplementation has no effect on conventional cardiovascular risk factors: a parallel-group, double-blind, placebo-controlled RCT. J Clin Endocrinol Metab 2012; 97:3557-68; PMID:22865902; http://dx.doi.org/10.1210/jc.20122126

48. Chandler PD, Scott JB, Drake BF, Ng K, Manson JE, Rifai N, Chan AT, Bennett GG, Hollis BW, Giovannucci EL, et al. Impact of vitamin D supplementation on inflammatory markers in African Americans: results of a four-arm, randomized, placebo-controlled trial. Cancer Prev Res (Phila) 2014; 7:218-25; PMID:24327720; http://dx.doi.org/10.1158/19406207.CAPR-13-0338-T

49. Bischoff-Ferrari HA, Dawson-Hughes B, Stöcklin E, Stöcklin E, Sidelnikov E, Willett WC, Edel JO, Stähelin HB, Wolfram S, Jetter A, et al. Oral supplementation with $25(\mathrm{OH}) \mathrm{D} 3$ versus vitamin D3: effects on $25(\mathrm{OH}) \mathrm{D}$ concentration, lower extremity function, blood pressure, and markers of innate immunity. J Bone Miner Res 2012; 27:160-9; PMID:22028071; http://dx.doi.org/10.1002/jbmr.551

50. Asemi Z, Samimi M, Tabassi Z, Shakeri H, Esmaillzadeh A. Vitamin D supplementation affects serum highsensitivity C-reactive protein, insulin resistance, and biomarkers of oxidative stress in pregnant women. J Nutr 2013; 143:1432-8; PMID:23884390; http://dx. doi.org/10.3945/jn.113.177550

51. Jorde R, Sneve M, Torjesen PA, Figenschau Y, Gøransson LG, Omdal R. No effect of supplementation with cholecalciferol on cytokines and markers of inflammation in overweight and obese subjects. Cytokine 2010; 50:175-80; PMID:20122848; http://dx.doi.org/ 10.1016/j.cyto.2009.12.006

52. Beilfuss J, Berg V, Sneve M, Jorde R, Kamycheva E. Effects of a 1-year supplementation with cholecalciferol on interleukin-6, tumor necrosis factor-alpha and insulin resistance in overweight and obese subjects. Cytokine 2012; 60:870-4; PMID:22925537; http://dx.doi. org/10.1016/j.cyto.2012.07.032

53. Belenchia AM, Tosh AK, Hillman LS, Peterson CA Correcting vitamin D insufficiency improves insulin sensitivity in obese adolescents: a randomized controlled trial. Am J Clin Nutr 2013; 97:774-81; PMID:23407306; http://dx.doi.org/10.3945/ajcn.112. 050013

54. Carrillo AE, Flynn MG, Pinkston C, Markofski MM, Jiang Y, Donkin SS, Teegarden D. Vitamin D supplementation during exercise training does not alter inflammatory biomarkers in overweight and obese subjects. Eur J Appl Physiol 2012; 112:3045-52; PMID:22183086; http://dx.doi.org/10.1007/s00421011-2279-3

55. Zittermann A, Frisch S, Berthold HK, Götting C, Kuhn J, Kleesiek K, Stehle P, Koertke H, Koerfer R. Vitamin D supplementation enhances the beneficial effects of weight loss on cardiovascular disease risk markers. Am J Clin Nutr 2009; 89:1321-7; PMID:19321573; http://dx.doi.org/10.3945/ajcn.2008. 27004

56. Mason C, Xiao L, Imayama I, Duggan C, Wang CY, Korde L, McTiernan A. Vitamin D3 supplementation during weight loss: a double-blind randomized controlled trial. Am J Clin Nutr 2014; 99:1015-25; PMID:24622804; http://dx.doi.org/10.3945/ajcn.113. 073734

57. Wamberg L, Kampmann U, Stødkilde-Jørgensen H, Rejnmark L, Pedersen S, Richelsen B. Effects of vitamin D supplementation on body fat accumulation, inflammation, and metabolic risk factors in obese adults with low vitamin D concentration - results from a randomized trial. Eur J Intern Med 2013; 24:644-9; PMID:23566943; http://dx.doi.org/10.1016/j.ejim 2013.03.005

58. Hopkins MH, Owen J, Ahearn T, Fedirko V, Flanders WD, Jones DP, Bostick RM. Effects of supplemental vitamin $\mathrm{D}$ and calcium on biomarkers of inflammation in colorectal adenoma patients: a randomized, controlled clinical trial. Cancer Prev Res (Phila) 2011; 4:1645-54; PMID:21724580; http://dx.doi.org/ 10.1158/1940-6207.CAPR-11-0105

59. Rahimi-Ardabili H, PourghassemGargari B, Farzadi L. Effects of vitamin D on cardiovascular disease risk factors in polycystic ovary syndrome women with vitamin D deficiency. J Endocrinol Invest 2013; 36:28-32; PMID:22453059

60. Sinha-Hikim I, Duran P, Shen R, Lee M, Friedman TC, Davidson MB. Effect of long term vitamin D supplementation on biomarkers of inflammation in Latino and African-American subjects with pre-diabetes and hypovitaminosis D. Horm Metab Res. 2014. [Epub ahead of print]; PMID:25011019

61. Yiu YF, Yiu KH, Siu CW, Chan YH, Li SW, Wong LY, Lee SW, Tam S, Wong EW, Lau CP, et al. Randomized controlled trial of vitamin D supplement on endothelial function in patients with type 2 diabetes. Atherosclerosis 2013; 227:140-6; PMID:23298824; http://dx.doi.org/10.1016/j.atherosclerosis.2012.12. 013

62. Breslavsky A, Frand J, Matas Z, Boaz M, Barnea Z, Shargorodsky M. Effect of high doses of vitamin D on arterial properties, adiponectin, leptin and glucose homeostasis in type 2 diabetic patients. Clin Nutr 2013; 32:970-5; PMID:23561637; http://dx.doi.org/ 10.1016/j.clnu.2013.01.020

63. Grimnes G, Figenschau Y, Almås B, Jorde R. Vitamin $\mathrm{D}$, insulin secretion, sensitivity, and lipids: results from a case-control study and a randomized controlled trial using hyperglycemic clamp technique. Diabetes 2011; 60:2748-57; PMID:21911741; http://dx.doi.org/ $10.2337 / \mathrm{db} 11-0650$

64. Shab-Bidar S, Neyestani TR, Djazayery A, Eshraghian MR, Houshiarrad A, Kalayi A, Shariatzadeh N, Khalaji $\mathrm{N}$, Gharavi A. Improvement of vitamin D status resulted in amelioration of biomarkers of systemic inflammation in the subjects with type 2 diabetes. Diabetes Metab Res Rev 2012; 28:424-30; PMID:22344966; http://dx.doi.org/10.1002/dmrr. 2290

65. Kampmann U, Mosekilde L, Juhl C, Moller N, Christensen B, Rejnmark L, Wamberg L, Orskov L. Effects of 12 weeks high dose vitamin D3 treatment on insulin sensitivity, beta cell function, and metabolic markers in patients with type 2 diabetes and vitamin D insufficiency - a double-blind, randomized, placebo-controlled trial. Metabolism 2014; 63:1115-24; PMID:25044176; http://dx.doi.org/10.1016/j. metabol.2014.06.008

66. Bucharles S, Barberato SH, Stinghen AE, Gruber B, Piekala L, Dambiski AC, Custodio MR, Pecoits-Filho R. Impact of cholecalciferol treatment on biomarkers of inflammation and myocardial structure in hemodialysis patients without hyperparathyroidism. J Ren Nutr 2012; 22:284-91; PMID:21908203; http://dx.doi.org/ 10.1053/j.jrn.2011.07.001

67. Alvarez JA, Zughaier SM, Law J, Hao L, Wasse H, Ziegler TR, Tangpricha V. Effects of high-dose cholecalciferol on serum markers of inflammation and immunity in patients with early chronic kidney disease. Eur J Clin Nutr 2013; 67:264-9; PMID:23361158; http://dx.doi. org/10.1038/ejcn.2012.217

68. Sokol SI, Srinivas V, Crandall JP, Kim M, Tellides G, Lebastchi AH, Yu Y, Gupta AK, Alderman MH. The effects of vitamin $\mathrm{D}$ repletion on endothelial function and inflammation in patients with coronary artery disease. Vasc Med 2012; 17:394-404; PMID:23184900; http://dx.doi.org/10.1177/1358863X12466709

69. Stricker H, TosiBianda F, Guidicelli-Nicolosi S, Limoni C, Colucci G. Effect of a single, oral, high-dose vitamin D supplementation on endothelial function in patients with peripheral arterial disease: a randomised controlled pilot study. Eur J Vasc Endovasc Surg 2012; 44:307-12; PMID:22831874 http://dx.doi.org/ 10.1016/j.ejvs.2012.06.023

70. Witham MD, Crighton LJ, Gillespie ND, Struthers $\mathrm{AD}$, McMurdo ME. The effects of vitamin D supplementation on physical function and quality of life in older patients with heart failure: a randomized controlled trial. Circ Heart Fail 2010; 3:195-201; PMID:20103775 http://dx.doi.org/10.1161/ CIRCHEARTFAILURE.109.907899

71. Schleithoff SS, Zittermann A, Tenderich G, Berthold HK, Stehle P, Koerfer R. Vitamin D supplementation improves cytokine profiles in patients with congestive heart failure: a double-blind, randomized, placebo-controlled trial. Am J Clin Nutr 2006; 83:754-9; PMID:16600924

72. Longenecker CT, Hileman CO, Carman TL, Ross AC, Seydafkan S, Brown TT, Labbato DE, Storer N, Tangpricha V, McComsey GA. Vitamin D supplementation and endothelial function in vitamin D deficient HIVinfected patients: a randomized placebo-controlled trial. Antivir Ther 2012; 17:613-21; PMID:22293363; http://dx.doi.org/10.3851/IMP1983

73. Mahon BD, Gordon SA, Cruz J, Cosman F, Cantorn MT. Cytokine profile in patients with multiple sclerosis following vitamin D supplementation. J Neuroimmunol 2003; 134:128-32; PMID:12507780; http://dx. doi.org/10.1016/S0165-5728(02)00396-X

74. Pappa HM, Mitchell PD, Jiang H, Kassiff S, FilipDhima R, DiFabio D, Quinn N, Lawton RC, Bronzwaer ME, Koenen $M$, et al. Maintenance of optimal vitamin $\mathrm{D}$ status in children and adolescents with inflammatory bowel disease: a randomized clinical trial comparing two regimens. J Clin Endocrinol Metab 2014; 99:3408-17; PMID: 24926949; http://dx.doi. org/10.1210/jc.2013-4218

75. Grossmann RE, Zughaier SM, Liu S, Lyles RH, Tangpricha V. Impact of vitamin $\mathrm{D}$ supplementation on markers of inflammation in adults with cystic fibrosis hospitalized for a pulmonary exacerbation. Eur J Clin Nutr 2012; 66:1072-4; PMID:22805498; http://dx. doi.org/10.1038/ejcn.2012.82

76. Shedeed SA. Vitamin D supplementation in infants with chronic congestive heart failure. Pediatr Cardiol 2012; 33:713-9; PMID:22349668; http://dx.doi.org/ 10.1007/s00246-012-0199-6

77. Abou-Raya A, Abou-Raya S, Helmii M. The effect of vitamin D supplementation on inflammatory and hemostatic markers and disease activity in patients with systemic lupus erythematosus: a randomized placebocontrolled trial. J Rheumatol 2013; 40:265-72; PMID:23204220; http://dx.doi.org/10.3899/jrheum. 111594

78. Hansen KE, Bartels CM, Gangnon RE, Jones AN, Gogineni J. An evaluation of high-dose vitamin D for rheumatoid arthritis. J Clin Rheumatol 2014; 20:1124; PMID:24561419

79. Arnson Y, Itzhaky D, Mosseri M, Barak V, Tzur B, Agmon-Levin N, Amital H. Vitamin D inflammatory cytokines and coronary events: a comprehensive review. Clin Rev Allergy Immunol 2013; 45:236-47; PMID:23314982; http://dx.doi.org/10.1007/s12016013-8356-0

80. Coussens AK, Wilkinson RJ, Hanifa Y, Nikolayevskyy V, Elkington PT, Islam K, Timms PM, Venton TR, Bothamley GH, Packe GE, et al. Vitamin D accelerates resolution of inflammatory responses during tuberculosis treatment. Proc Natl Acad Sci U S A 2012; 109:15449-54; PMID:22949664; http://dx.doi.org/ $10.1073 /$ pnas. 1200072109

81. http://www.hutchon.net/confidrr.htm (accessed August $16,2014)$

82. Grant WB. Relation between prediagnostic serum 25hydroxyvitamin D level and incidence of breast, colorectal, and other cancers. J Photochem Photobiol B 
2010; 101:130-6; PMID:20570169; http://dx.doi.org/ 10.1016/j.jphotobiol.2010.04.008

83. Wang L, Song Y, Manson JE, Pilz S, März W, Michaëlsson K, Lundqvist A, Jassal SK, Barrett-Connor E, Zhang C, et al. Circulating 25-hydroxy-vitamin D and risk of cardiovascular disease: A meta-analysis of prospective studies. Circ Cardiovasc Qual Outcomes 2012; 5:819-29; PMID:23149428; http://dx.doi.org/ 10.1161/CIRCOUTCOMES.112.967604

84. Heaney RP. Guidelines for optimizing design and analysis of clinical studies of nutrient effects. Nutr Rev 2014; 72:48-54; PMID:24330136; http://dx.doi.org/ $10.1111 /$ nure. 12090

85. Manson JE, Bassuk SS, Lee IM, Cook NR, Albert MA Gordon D, Zaharris E, Macfadyen JG, Danielson E, Lin J, et al. The VITamin D and OmegA-3 TriaL (VITAL): rationale and design of a large randomized controlled trial of vitamin D and marine omega-3 fatty acid supplements for the primary prevention of cancer and cardiovascular disease. Contemp Clin Trials 2012; 33:159-71; PMID:21986389; http://dx.doi.org/ 10.1016/j.cct.2011.09.009
86. Cimmino MA, Parodi M, Montecucco C, Caporali R. The correct prednisone starting dose in polymyalgia rheumatica is related to body weight but not to disease severity. BMC Musculoskelet Disord 2011; 12:94; PMID:21569559; http://dx.doi.org/10.1186/1471-2474-12-94

87. Stamp TC, Haddad JG, Twigg CA. Comparison of oral 25-hydroxycholecalciferol, vitamin $\mathrm{D}$, and ultraviolet light as determinants of circulating 25-hydroxyvitamin D. Lancet 1977; 1:1341-3; PMID:69059; http:// dx.doi.org/10.1016/S0140-6736(77)92553-3

88. Vieth R. Vitamin D supplementation, 25-hydroxyvitamin D concentrations, and safety. Am J Clin Nutr 1999; 69:842-56; PMID:10232622

89. Soilu-Hanninen M, Aivo J, Lindstrom BM, Elovaara I, Sumelahti ML, Färkkilä M, Tienari P, Atula S, Sarasoja T, Herrala L, et al. A randomised, double blind, placebo controlled trial with vitamin $\mathrm{d} 3$ as an add on treatment to interferon $\beta-1 \mathrm{~b}$ in patients with multiple sclerosis. J Neurol Neurosurg Psychiatry 2012; 83:56571; PMID:22362918; http://dx.doi.org/10.1136/jnnp2011-301876
90. Salahuddin N, Ali F, Hasan Z, Rao N, Aqeel M, Mahmood F. Vitamin D accelerates clinical recovery from tuberculosis: results of the SUCCINCT Study [Supplementary cholecalciferol in recovery from tuberculosis]. A randomized, placebo-controlled, clinical trial of vitamin D supplementation in patients with pulmonary tuberculosis'. BMC Infect Dis 2013; 13: 22, PMID:23331510; http://dx.doi.org/10.1186/14712334-13-22

91. Dehghan A, Rahimpour S, Soleymani-Salehabadi H, Owlia MB. Role of vitamin D in flare ups of rheumatoid arthritis. Z Rheumatol 2014; 73:461-4; PMID:24352479; http://dx.doi.org/10.1007/s00393013-1297-4

92. Cutillas-Marco E, Marquina-Vila A, Grant W, VilataCorell J, Morales-Suárez-Varela M. Vitamin D and cutaneous lupus erythematosus: effect of vitamin D replacement on disease severity. Lupus 2014 Feb 6. [Epub ahead of print]; PMID:24503020

93. Kimball SM, Ursell MR, O'Connor P, Vieth R. Safety of vitamin D3 in adults with multiple sclerosis. Am J Clin Nutr 2007; 86:645-51; PMID:17823429 